\title{
DEPOCEN
}

Working Paper Series No. 2007/03

\section{Does Macroeconomic Transparency Help Governments Be Solvent? Evidence from Recent Data}

\author{
Ramzi Mallat* \\ Duc Khuong Nguyen**
}

* EM Lyon Business School \& University of Lyon 2

88 Rue Pasteur, 69007 Lyon, France

** Professor of Finance, ISC Paris School of Management

22 Boulevard du Fort de Vaux, 75848 Paris cedex 17, France

The DEPOCEN WORKING PAPER SERIES disseminates research findings and promotes scholar exchanges in all branches of economic studies, with a special emphasis on Vietnam. The views and interpretations expressed in the paper are those of the author(s) and do not necessarily represent the views and policies of the DEPOCEN or its Management Board. The DEPOCEN does not guarantee the accuracy of findings, interpretations, and data associated with the paper, and accepts no responsibility whatsoever for any consequences of their use. The author(s) remains the copyright owner.

DEPOCEN WORKING PAPERS are available online at http://www.depocenwp.org 


\title{
Does macroeconomic transparency help governments be solvent? Evidence from recent data
}

\author{
Ramzi Mallat ${ }^{\mathrm{a}}$ \\ ${ }^{a}$ EM Lyon Business School \& University of Lyon 2 \\ 88 Rue Pasteur, 69007 Lyon, France \\ mallat@em-lyon.com \\ and \\ Duc Khuong Nguyen ${ }^{\mathrm{b} *}$ \\ ${ }^{b}$ Professor of Finance, ISC Paris School of Management \\ 22 Boulevard du Fort de Vaux, 75848 Paris cedex 17, France \\ dnguyen@groupeisc.com
}

\begin{abstract}
This paper investigates whether macroeconomic and data transparency standards lead to lower borrowing costs in sovereign bond markets. We essentially show that emerging market countries which subscribed to the Special Data Dissemination Standard (SDDS) experienced a significant decline in borrowing cost proxied by sovereign yield spreads on secondary markets. However, the adherence of these markets to the Code of Good Practices on Transparency in Monetary and Financial Policies caused a significant increase in the yield spreads. There is no impact of the adherence to the Code of Good Practices in Fiscal Transparency on the changes of sovereign spreads. In addition, the results suggest that a debtor country's internal liquidity factor (measured by the total reserves to total external debt service ratio) and external liquidity conditions (measured by the yield on US longterm bond) are the most important determinants of emerging market spreads.
\end{abstract}

JEL Classifications: C23, E42, F34, G18

Key words: emerging markets, transparency, standards and codes, international financial architecture, sovereign debt and yield spreads

\footnotetext{
* We have greatly benefited from comments and suggestions by Georges Pariente, Mondher Bellalah and participants at the $4^{\text {th }}$ International Finance Conference (March 14-17, 2007, Hammamet, Tunisia).

Corresponding author: Duc K. NGUYEN, 22 Boulevard du Fort de Vaux, 75848 Paris cedex 17, France.
} 


\section{INTRODUCTION}

The debt market in emerging market countries consists of sovereign debt and corporate debt, of which sovereign debt segment has become, in recent years, an integral part of the global fixed income investment landscape given their size and rapid growth. Therefore, understanding emerging market debt and its return-risk profile is of great interest.

One of the stylized facts of sovereign debt markets in emerging countries is the Mexican financial crisis in 1994-95 because its occurrence revealed the need for better information available to the public and financial market players. More generally, the emerging market crises during the 1990s have generated considerable debate among officials, researchers, institutional investors and the international community about the role of transparency as an explanation of the triggering of crises and further on its role in international financial stability. The adoption of internationally recognized standards and codes of best practices came to be seen as a way to strengthen international financial system. This was thought to be necessary for markets to make prudent lending and investment decisions. While many agree that greater availability of information would not by itself be sufficient to prevent financial crises, it was nevertheless generally accepted that disclosure and transparency are necessary to improve the International Financial Architecture.

Then, actions in the international community has initially got started on setting standards for improving, on the one hand, the timeliness and quality of information contained in key macroeconomic variables and on the other hand, the transparency of public sector activities including fiscal, monetary and financial policies. In particular, we recognize the IMF’s efforts devoted to the establishment of the data and macroeconomic policy transparency standards whose aims are to improve timely release of economic and financial data to the public as well as information on their compilation procedures. Most importantly, the IMF member countries have been engaged to adopt, on voluntary basis, those international standards and 
codes of good practices to help their economies and financial systems function properly at the national and international levels, and to share with the public timely and accurate data.

So far, several studies have examined the impact of standards and codes on emerging market economies' borrowing costs and access to international capital markets by measuring their effect on sovereign bond spreads, which are generally considered to be a measure of the market's perception of the probability of future crises. The empirical evidence according to which the borrowing costs are reduced for emerging market adhering to internationally recognized standards has been presented (see, e.g., Gelos and Wei, 2002; Christofides, Mulder and Tiffin, 2003; Glennerster and Shin, 2003; Cady, 2005). Albeit their great contribution in understanding the effect of macroeconomic and data transparency, these studies mainly concentrated, however, on the impact of the international standards and codes on the spreads of the primary debt market. Then, there is still a need for empirical findings in the secondary markets.

This present paper attempts to fill this gap by evaluating the impact of the data and macroeconomic transparency standards on sovereign bond spreads of emerging markets as a measure of the borrowing costs. We focus on the following standards and codes: the Special Data Dissemination Standards, the Code of Good Practices on Transparency in Monetary and Financial Policies, and the Code of Good Practices on Fiscal Policy Transparency. Using data on Emerging Market Bond Index spread, we show that the SDDS subscription leads to significantly reduce the borrowing costs of emerging markets' issuers. The adherence to monetary and financial policy transparency codes generates a significant impact on the sovereign spreads, but the sign of the effect remains difficult to interpret. The fiscal policy transparency codes have an insignificant effect on the spreads.

The remainder of this paper is organized as follows. Section 2 presents the economic background of the studied problem and a brief review of literature. Section 3 discusses the 
empirical approach. Section 4 describes the data used in the paper. Section 5 reports and interprets the obtained results. Summary remarks and policy implications are provided in Section 6.

\section{ECONOMIC MOTIVATIONS AND LITERATURE REVIEW}

In the aftermath of the Mexican financial crisis (1994) and especially the East Asian crisis, the international community has been engaged in reforming the so-called International Financial Architecture. Of the possible explanations for the advent of these crises, the lack of transparency has received great attention and has been widely discussed. International financial institutions and governments of creditor countries claimed that lack of relevant information may produce triggered or exacerbated crises leading to contagion and herding behaviour. To be aware of the essential role of data transparency in reducing the likelihood of financial crises (thus strengthening the international financial stability), the international community called for the release of timely dissemination of macroeconomic and financial data to market participants.

Given its role in promoting greater financial stability in global context, the IMF engaged in the establishment of different standards and codes concerning the timing and availability of macroeconomic data. Its work on data dissemination standards began in October 1995 just after the occurrence of the Mexican crisis. The aim of these standards is to provide a conceptual framework for countries that might seek access to international capital markets to render public their economic and financial data through the availability of timely and comprehensive statistics. This clearly contributes to incite the pursuit of sound macroeconomic policies and to get better functioning of financial markets. These standards are named Special Data Dissemination Standards (SDDS) which were approved by the IMF Executive Board in March 1996. On September 26, 1999, the Interim Committee (currently called the Interna- 
tional Monetary and Financial Committee) adopted the Code of Good Practices on Transparency in Monetary and Financial Policies, designated to guide member countries to increase transparency in the conduct of these policies. Two year later, the Executive Board of Directors of the IMF approved the Code of Good Practices on Fiscal Transparency on March 23, 2001. The objective of this code is to provide member countries to increase their transparency through better informing the public about the design and results of fiscal policy, making governments more accountable for the implementation of fiscal policy, and thereby strengthening credibility and public understanding of macroeconomic policies.

It is also important to mention that the establishment of the Financial Stability Forum in February 1999 by the G7 finance ministers and central bank governors was a response to the willingness of the international community to promote the adoption and implementation of these standards both inside countries and globally. To date, each country has at its disposal the list of the various economic and financial standards that are considered as important for sound, stable and well functioning financial systems as indicated in the appendix.

The apparition of internationally recognized standards and codes raises some intriguing questions. Among other things, one may wonder to know the relationship between standards and codes on the one hand, and their economic outcomes on the other hand. Several studies have empirically examined the effect of international standards and codes on emerging market economies’ sovereign bond spreads. For instance, Chortareas et al. (2001) found that countries which release more macroeconomic data have lower inflation rate. Gelos and Wei (2002) proved, in addition to the conclusion of Chortareas et al. (2001), that these countries attract more foreign direct investment inflows. In a recent study, Christofides, Mulder and Tiffin (2003) showed that the subscription to international standards contributed significantly to explain changes in sovereign credit spreads and ratings. The Institute of International Finance (2002) and Glennerster and Shin (2003) provided evidence that the sovereign 
risk premium in emerging markets is significantly reduced after the subscription to international standards. Cady (2005) used data on launch credit spreads and reached similar conclusion as in Glennerster and Shin (2003). Finally, in a related study, Andritzky and al. (2007) found that macroeconomic and data announcement effects in emerging market bonds reduce uncertainty and contribute to stabilize spreads. This result particularly leads to think about an eventual diminution of spread levels

Our paper is part of the above literature, but it is different in two crucial points. First, we focus on the secondary markets and not on the primary markets as in the majority of previous studies. The rationale behind this proving ground lays on the fact that secondary markets better reflect the changes in investors' sentiment about the engagement of one country to improve the accuracy and frequency of macroeconomic information released to the public. Second, we only relate the evolution of emerging market bond spreads to three most important international standards and codes: the SDDS, the monetary and financial policy transparency, and the fiscal policy transparency. Meanwhile, by adopting this choice, our study is not general like that of Christofides, Mulder and Tiffin (2003) in the sense that these authors investigated a greater number of standards and codes.

\section{MODEL AND ESTIMATION ISSUES}

We assess the impact of macroeconomic and data transparency represented by the Monetary and Financial Transparency, the Fiscal Transparency and the SDDS on the difference in emerging market countries' mean sovereign credit spreads using a pooled time-series crosssectional model with fixed effects of the following form (see, Edwards, 1984) ${ }^{1}$ :

$$
\log \left(S P_{i}\right)=\alpha_{i}+\sum_{j=1}^{J} \beta_{j} X_{j i t}+\varepsilon_{i} \quad(i=1,2, \ldots N ; t=1,2, \ldots T)
$$

In this specification, $\log \left(S P_{i}\right)$ refers to a continuous dependent variable which is measured by the logarithm of the EMBIG spread for the emerging country $i . X_{j i t}$ refers to the 
explanatory variable $j$ for the country $i$ at time $t$. The intercept coefficient $\alpha_{i}$ reflects the country $i$ 's characteristics that are assumed to be unchanged over the estimation period. $\beta_{j}$ refers to slope parameters of a specific explanatory variable $j$ that captures the common effect of that variable on the sovereign credit spread movements. $\varepsilon_{t}$ is a random error term. $N$ is the total number of cross-sections included in the empirical model. $T$ stands for the total number of observations of the panel data set.

Here, the set of explanatory variables includes a dummy variable which represents the subscription date of each country to newly introduced international codes and standards, and ten macroeconomic fundamentals. Since our study focuses on the FPT, the MFPT and the SDDS, three alternative models will be estimated. To be more precise, dummy variables are of our preliminary interest because they controls for the changes in the sovereign spreads before and after an emerging country decided to become more transparent via a publication of the related standards. They take the value of one from the subscription date to the end of the study period and zero otherwise. If the enhanced macroeconomic and data transparency leads to reduce the country default risk, all dummy variables are expected to exercise a negative and significant influence on the EMBIG spread fluctuations. Macroeconomic fundamentals are introduced in the empirical model for two main reasons. First, their presence offers an easy framework to isolate the specific effects of the transparency factor because sovereign spreads' movements also depend on the changing macroeconomic conditions. Second, by doing so, we are able, just similar to previous studies, to identify the determinants of the sovereign spreads whose level is informative of the quality of emerging market debt issuers. Effectively, we construct the following macroeconomic variables ${ }^{2}$ : the inflation rate or the growth rate of changes in the consumer price index (CPI), the budget deficit as a share of GDP (BUD/GDP), the ratio of total external debt to GDP (DEBT/GDP), the ratio of total imports plus exports to GDP (TRA/GDP), the ratio of total current account to GDP 
(CUR/GDP), the ratio of total interest amount to GDP (INT/GDP), the liquidity ratio measured as the total of reserves in proportion of the total external debt service (RES/DEBT), the growth rate of GDP denominated in local currency (GROWTH), the logarithm of the US federal funds interest rate (USFED) and the logarithm of the yield on the 10-year US Treasury bond (USLONG). By default, these variables mirror the general monetary and liquidity conditions in sample emerging markets.

The estimation of the time-series cross-sectional model is often carried out by using Ordinary Least Squares (OLS) procedure. As widely discussed in econometric literature, this model permits to solve many problems of traditional methods of the comparative research which employs either time series analysis or cross-sectional analysis. For instance, the limited number of spatial units in cross-sectional analysis and the limited number of available data over time (i.e., small ' $N$ ' and ' $T$ ') often lead these two individual techniques to violate basic assumptions of standard OLS analysis. Most obviously, estimated results are largely biased if the model contains many explanatory variables comparatively to very few observations. In this schema of things, the pooled time-series cross-sectional design allows the removal of this restriction because the number of observations is now the product between $N$ and $T$. This feature is also useful in that one can easily set a framework allowing for a multivariate analysis (i.e., large number of independent variables). Next, pooled time-series cross-sectional models offer the possibility to investigate not only the variation of what emerges through time or space, but also the variation of these two dimensions simultaneously. The reason is that, instead of testing a cross-section model for all countries at one point in time or testing a timeseries model for one country using its time-series data, a pooled model is tested for all countries through time. Accordingly, the pooled time-series model with fixed effects we developed above is highly suitable to our problem of assessing the effects of sample countries' 
increased transparency because it captures both cross-sectional effect of explanatory variables on credit spreads as well as the time-series effect within markets.

It is, however, important to note that the pooled model encounters some methodological problems albeit advantageous for dealing with both time and space, of which the most important include the serial correlation between a country i's errors, the contemporaneous cross-sectional correlation of the errors, the cross-sectional heteroscedasticity of the errors and the possibly causal heterogeneity of parameters across cross-section units ${ }^{3}$ (see, e.g., Hicks, 1994; Beck and Katz, 1996). So, in this paper we employ the seemingly unrelated regression (SUR) method, also referred to as the Parks estimators, to correct for these estimation problems. In fact, the seemingly unrelated regression procedure treats each cross-section (or market) and the time series within that cross-section as a separate equation that is unrelated to any other cross-section and its time series in the pooled data set. Most specifically, this estimation procedure is interpretable as a series of a country specific regression analysis that utilizes contemporaneous cross-equation error correlations among the error of a system of equation to improve the efficiency of the estimates of an equation system (Hicks, 1994).

\section{DATA}

In this paper, the question of whether the improving macroeconomic and data transparency leads to lower yield spreads (or country risk reduction) in sovereign bond markets is investigated. Sample emerging markets include Argentina, Brazil, Croatia, Ecuador, Mexico, Turkey and South Africa. Quarterly data on yield spreads of the JP Morgan Emerging Market Index Global (EMBIG) are used over the period from January 1994 to December $2002^{4}$. The choice of EMBIG to the detriment of EMBI is explained by the wider range of debt instruments that the EMBIG covers. Recall that yield spread, often measured by the number of basis points, is the difference between the yield on emerging market bond index and the yield 
on a bond of similar characteristics, but considered as free of default risk (typically a US Treasury security). One basis point is equal to a hundredth of a percentage point. More detailed description of emerging market debt indices is provided in Cunningham (1999).

\section{[INSERT TABLE 1 HERE]}

Table 1 gives the summarized characteristics of our sample data. At the first sight, we observe that the sovereign spread is around 801 basis points on average with a highest value of 6475 which is equivalent to $67.75 \%$. Besides, it should be noted that the average deficit or surplus budget and the current deficit over GDP stand both at $-1 \%$; the inflation rate is somewhat high for sample markets because it comes to $74 \%$; the total external debt is near to $50 \%$ of the GDP; and finally the total reserves represent only $22 \%$ of the total external debt.

\section{[INSERT TABLE 2 HERE]}

Table 2 offers a close look on the dates of subscription of sample markets to different transparency policies. Our selected markets have mainly subscribed to the SDDS in 1996, except for Brazil and Ecuador. As regards to the FPT and MFPT, the newest subscription dates started in 1999, which clearly restrict the possibility to include a large number of countries in our sample. This also limits our interpretations of the empirical results in the later section.

\section{[INSERT FIGURE 1 HERE]}

Figure 1 depicts the evolution of the emerging market sovereign spreads over the first quarter of 1994 to the fourth quarter of 2002. As we can observe, sovereign debt markets in Argentina and Ecuador pay the highest spread level which particularly indicates the importance of default risk in these markets. If we look at the dates of subscription to the SDDS of sample markets, we are able to notify that credit spreads globally went down in the aftermath of the 1994 debt crisis in the Latin American region. The time-paths also testified an upward 
trend of credit spreads since the beginning of 1998, and that continued until the end of our study period.

To close this section, it is important to mention that data for the EMBIG spreads are drawn from JP Morgan and macroeconomic fundamentals and external debt variables are obtained from the IMF's International Financial Statistics. To preserve the country-specific factors, we construct all our variables based on local currency basis.

\section{EMPIRICAL RESULTS}

This section presents the empirical results from the estimation of our pooled model described in Section 3. Particularly, the results are divided into three groups depending on the types of subscription events (the SDDS, the FPT, or the MFPT). First, we study the impact of the SDDS subscription on the time-varying level of the EMBIG spreads by adding the dummy variable SDDS into our pooled time-series cross-sectional model. Next, the dummy variable SDDS is step by step replaced by the FPT and MFPT variables respectively. It is important to notify that the first model contains every market in the sample data whereas only markets which subscribed to the FPT and MFPT are included the second and the third models.

Table 3 reports the whole results from estimating our pooled model. Generally, there is a relatively high level of fit for three examined models since the adjusted R-squared ranges from $66.7 \%$ to $77.5 \%$. The significance of the majority of coefficients at conventional levels also indicates the correct selection of explanatory variables.

With regard to model 1 , our variable of interest is the dummy variable SDDS. The coefficient attached to this variable is, as expected, negative and significant at 5\%. Accordingly, for countries which subscribed to the Special Data Dissemination Standard, the crosscountry sovereign spreads decreases by $23.4 \%$. This is informative of the reduction of premium attributed to investors for holding the debt securities issued by emerging market bor- 
rowers. In this schema of things, policy makers will have an interest in improving data transparency to lower borrowing costs. It should be noted that the obtained result is in line with previous findings revealed by, among others, Christofides, Mulder and Tiffin (2003), and Cady (2005).

\section{[INSERT TABLE 3 HERE]}

Contrary to what we might expect, changes in the EMBIG spreads are not at all affected by the country's subscription to the fiscal policy transparency from the view of the coefficient associated with the FPT variable. That is, a better transparency in terms of fiscal policies does not necessarily conduct to lower spreads. For instance, this result is found at least for the countries which are included in the cross-sectional regression. Since the impact of the fiscal transparency on the sovereign spreads is, to our knowledge, never treated in previous literature, there is no possibility to compare our results.

Concerning the effect on the EMBIG spreads of the monetary and financial policy transparency; the result shows a positive and significant relationship between two variables of interest. Effectively, we observe an increase of 30.5\% in the spread levels after the subscription date of one country to the MFPT standard. Clearly, this impact is difficult to be interpreted. To give an explanation, one may think that the effect of other variables prevails that of the MFPT subscription during the recent years, and leads the sovereign spreads in most countries go up to their highest levels observed during the estimation period.

Like previous works which attempt to analyze the impact of macroeconomic fundamentals on the emerging market spreads, the present study also finds the dominant effect of the liquidity factor (cf. the ratio of total reserves to the total external debt) and the yield on 10-year US Treasury bond. In fact, the coefficient attached to the RES/DEBT variable is negative and highly significant, indicating that the more important is the liquidity, the more the spread will decrease. The same pattern is acknowledged in the case of the USLONG variable. 
This is explainable because an increase in the yield on the US long-term bond normally leads to lower the yield on bonds of similar characteristics. The other important determinants of the EMBIG spreads include the total external debt to GDP ratio and the total imports plus exports to GDP ratio.

\section{CONCLUSION}

The emerging market crises of the 1990s have generated considerable debate about the New International Financial Architecture (NIFA) and were partially attributed to a lack of market information. Improving transparency is considered as the main reform of this NIFA.

This paper investigated whether macroeconomic and data transparency standards lead to lower yield spreads in sovereign bond markets. The endogenous variable, sovereign credit spread, is taken from JP Morgan’s Emerging Market Bond Index Global. The factor of interest, the subscription to the Special Data Dissemination Standard (SDDS) is represented by a dummy variable that is set to be equal to one for the quarters following the subscription. We also consider the subscription to 'The Code of Good Practices on Transparency in Monetary and Financial Policies' and 'The Code of Good Practices in Fiscal Transparency'. The influence of other factors, mainly macroeconomic fundamentals and external debt variables which have been broadly considered in the literature (Kamin and Kleist, 1999; and Ferrucci, 2003) is controlled for.

Using quarterly data and a pooled time-series regression analysis, we found that the macroeconomic and data transparency leads to significantly lower spread levels only when the considered country subscribed to the SDDS. There is a significant response of the spread levels following the subscription to the monetary and financial policy transparency standards; however the impact is positive and therefore difficult to be interpreted. The adoption of the fiscal policy transparency has no significant impact on the spreads. In addition, macroeco- 
nomic fundamentals seem to play an important role in the determination of the borrowing cost in debt markets of emerging countries. Of which, the most important factors are the liquidity and the yield on the US long-term bond. In this schema of things, policy makers will have an interest in improving data transparency and liquidity factor to lower borrowing costs. 


\section{NOTES}

${ }^{1}$ The log-linear relationship of the sovereign spread determinants is derived from assuming the risk neutral lenders and the competitive financial market. In the more complex context, Feder and Just (1977), Eaton and Gersovitz (1980), and Sachs (1981) obtained the similar relationship.

${ }^{2}$ Most of these variables have been used in the previous literature and have been found to have a significant impact on sovereign credit spreads (see, for example, Eichengreen and Mody, 2000; Min and al., 2003; Jüttner and $a l .$, 2006).

${ }^{3}$ In some cases, the slope coefficients of the pooled model are heterogeneous across crosssection units because the errors tend to be nonrandom. Then, the assumed homogeneity of slope coefficients might be not reasonable.

${ }^{4}$ To measure the historical performance of emerging market debt, JP Morgan publishes two main variants of sovereign bond indices. The first measure, called Emerging Market Bond Index, tracks returns and spreads on Brady bonds and some other restructured sovereign instruments in emerging market countries. The second measure is the Emerging Market Bond Index Global (EMBIG), which is designated to track the total returns for dollar-denominated Brady bonds, Eurobonds, traded loans and local market debt instruments issued by sovereign and quasi-sovereign entities of emerging markets countries. Currently, the EMBI Global covers 188 instruments across 33 emerging countries. For being selected in these indices, sovereign debt instruments must have a face value of over US\$500 million and at least 2.5 years to maturity, and they must also pass a liquidity test. 
Table 1 - Basic statistics of the cross-sectional data

\begin{tabular}{l|rrrrrr}
\hline & Mean & Std. Dev. & Maximum & Minimum & Jarque-Bera & Probability \\
\hline SP (Spread) & 801.00 & 938.95 & 6475.00 & 80.00 & 3109.21 & 0.00 \\
BUD/GDP & -0.01 & 0.01 & 0.01 & -0.05 & 138.84 & 0.00 \\
CPI & 0.74 & 4.05 & 44.53 & -0.02 & 64053.32 & 0.00 \\
CUR/GDP & -0.01 & 0.01 & 0.06 & -0.07 & 277.28 & 0.00 \\
DEBT/GDP & 0.47 & 0.24 & 1.38 & 0.14 & 86.88 & 0.00 \\
GROWTH & 0.06 & 0.08 & 0.37 & -0.11 & 139.00 & 0.00 \\
INT/GDP & 0.03 & 0.01 & 0.07 & 0.01 & 21.61 & 0.00 \\
RES/DEBT & 0.22 & 0.11 & 0.68 & 0.05 & 177.99 & 0.00 \\
TRA/GDP & -0.01 & 0.02 & 0.04 & -0.09 & 102.14 & 0.00 \\
USFED & 0.05 & 0.01 & 0.07 & 0.01 & 62.32 & 0.00 \\
USLONG & 0.06 & 0.01 & 0.08 & 0.04 & 1.45 & 0.48 \\
\hline
\end{tabular}

Notes: this table provides basic statistics of the cross-section data used in our study. The dependent variable is none other than the logarithm of the Emerging Market Bond Index Global spreads. BUD/GDP, CPI, CUR/GDP, DEBT/GDP, DEBT/GDP, GROWTH, INT/GDP, RES/DEBT, TRA/GDP, USFED and USLONG refer respectively to the ratio of budget deficit to GDP, the inflation rate, the ratio of total current account to GDP, the ratio of total external debt to GDP, the growth rate of GDP denominated in local currency, the ratio of total interest amount to GDP, the liquidity ratio measured as the total of reserves in proportion of the total external debt service, the ratio of total imports plus exports to GDP (TRA/GDP), the logarithm of the US federal funds interest rate and the logarithm of the yield on the 10-year US Treasury bond. These macroeconomic fundamentals are used in order to control for the general macroeconomic conditions of sample countries. 
Table 2 - Subscription dates of sample markets to the Special Data Dissemination Standards (SDDS), Fiscal Policy Transparency (FPT) and Monetary and Financial Policy Transparency (MFPT)

\begin{tabular}{l|rrr}
\hline \multicolumn{1}{c|}{ Country } & $\begin{array}{r}\text { Date of SDDS } \\
\text { subscription }\end{array}$ & $\begin{array}{r}\text { Date of FPT } \\
\text { subscription }\end{array}$ & $\begin{array}{r}\text { Date of MFPT } \\
\text { subscription }\end{array}$ \\
\hline Argentina & August 16, 1996 & April 15, 1999 & April 15, 1999 \\
Brazil & March 14, 2001 & December 6, 2001 & Nonsubscriber \\
Croatia & May 20, 1996 & November 24, 2004 & August 12, 2002 \\
Ecuador & March 27, 1998 & Nonsubscriber & Nonsubscriber \\
Mexico & August 13, 1996 & September 16, 2002 & October 11, 2001 \\
South Africa & August 2, 1996 & Nonsubscriber & Nonsubscriber \\
Turkey & August 8,1996 & June 27, 2000 & Nonsubscriber \\
\hline
\end{tabular}


Table 3 - Estimation results from the pooled time-series model with fixed effects

\begin{tabular}{|c|c|c|c|}
\hline Variables & Model 1 & Model 2 & Model 3 \\
\hline Budget deficit to GDP ratio (BUD/GDP) & $\begin{array}{c}-2.136 \\
(-0.709)\end{array}$ & $\begin{array}{c}-11.764^{* * *} \\
(-2.343)\end{array}$ & $\begin{array}{c}-6.688 \\
(-1.037)\end{array}$ \\
\hline Inflation rate (CPI) & $\begin{array}{c}0.010^{*} \\
(1.719)\end{array}$ & $\begin{array}{c}0.007 \\
(1.012)\end{array}$ & $\begin{array}{c}-0.081 \\
(-0.970)\end{array}$ \\
\hline Current account to GDP ratio (CUR/GDP) & $\begin{array}{c}0.143 \\
(0.058)\end{array}$ & $\begin{array}{c}26.470^{* *} \\
(2.452)\end{array}$ & $\begin{array}{c}-0.906 \\
(-0.313)\end{array}$ \\
\hline Total external debt to GDP ratio (DEBT/GDP) & $\begin{array}{l}0.640^{* *} \\
(2.941)\end{array}$ & $\begin{array}{l}1.457^{* *} \\
(3.174)\end{array}$ & $\begin{array}{c}0.530 \\
(1.291)\end{array}$ \\
\hline Growth rate of GDP (GROWTH) & $\begin{array}{c}-1.038 \\
(-2.639)\end{array}$ & $\begin{array}{c}-0.556 \\
(-1.003)\end{array}$ & $\begin{array}{c}-0.179 \\
(-0.231)\end{array}$ \\
\hline Interest to GDP ratio (INT/GDP) & $\begin{array}{c}-1.051 \\
(-0.274)\end{array}$ & $\begin{array}{c}-9.602 \\
(-1.355)\end{array}$ & $\begin{array}{c}-29.429^{*} \\
(-3.588)\end{array}$ \\
\hline Total reserves to total external debt (RES/DEBT) & $\begin{array}{l}-2.512^{* *} \\
(-5.725)\end{array}$ & $\begin{array}{l}-3.218^{* *} \\
(-4.140)\end{array}$ & $\begin{array}{l}-4.165^{* *} \\
(-5.420)\end{array}$ \\
\hline Total trade sector to GDP (TRA/GDP) & $\begin{array}{c}18.257^{* *} \\
(4.813)\end{array}$ & $\begin{array}{l}-11.761 \\
(-0.903)\end{array}$ & $\begin{array}{c}29.333^{* *} \\
(5.122)\end{array}$ \\
\hline Federal funds rate (USFED) & $\begin{array}{c}0.022 \\
(0.214)\end{array}$ & $\begin{array}{c}0.080 \\
(0.610)\end{array}$ & $\begin{array}{l}0.401^{* *} \\
(2.128)\end{array}$ \\
\hline 10-year US Treasury bond (USLONG) & $\begin{array}{l}-0.572^{*} \\
(-1.777)\end{array}$ & $\begin{array}{c}-0.405 \\
(-1.211) \\
\end{array}$ & $\begin{array}{c}-0.702^{*} \\
(-1.751)\end{array}$ \\
\hline Subscription date to the SDDS (SDDS) & $\begin{array}{l}-0.234^{* *} \\
(-2.947)\end{array}$ & & \\
\hline Subscription date to the FPT (FPT) & & $\begin{array}{c}0.191 \\
(1.418)\end{array}$ & \\
\hline Subscription date to the MFPT (MFPT) & & & $\begin{array}{c}0.305^{*} \\
(1.691) \\
\end{array}$ \\
\hline Fixed Effects & & & \\
\hline South Africa-C & 3.798 & & \\
\hline Argentina--C & 5.431 & 5.942 & 7.012 \\
\hline Brazil-C & 5.550 & 6.436 & \\
\hline Croatia-C & 6.033 & & 8.407 \\
\hline Ecuador-C & 5.472 & & \\
\hline Mexico-C & 5.340 & 5.893 & 6.915 \\
\hline Turkey-C & 5.294 & 4.901 & \\
\hline R-squared & 0.791 & 0.702 & 0.724 \\
\hline Adjusted R-squared & 0.775 & 0.667 & 0.686 \\
\hline
\end{tabular}

Notes: this table reports the estimated coefficients from estimating the general pooled model. In model 1, we relate the evolution of the EMBIG spreads to a set of one dummy variable (SDDS) and ten explanatory variables which consist of macroeconomic fundamentals. The models 2 and 3 are quite similar to the model 1 with a small difference. That is, instead of the dummy variable SDDS, we use respectively the dummy variables FPT and MFPT. The number of cross-sections (or countries) is equal to 7, 4 and 3 for models 1,2 and 3 respectively. and ${ }^{* *}$ indicate that the associated coefficient is statistically significant at $10 \%$ and $5 \%$ respectively. The tstatistics are reported in parentheses. 
Figure 1 - The evolution of EMBIG spreads over the period 1994-2002

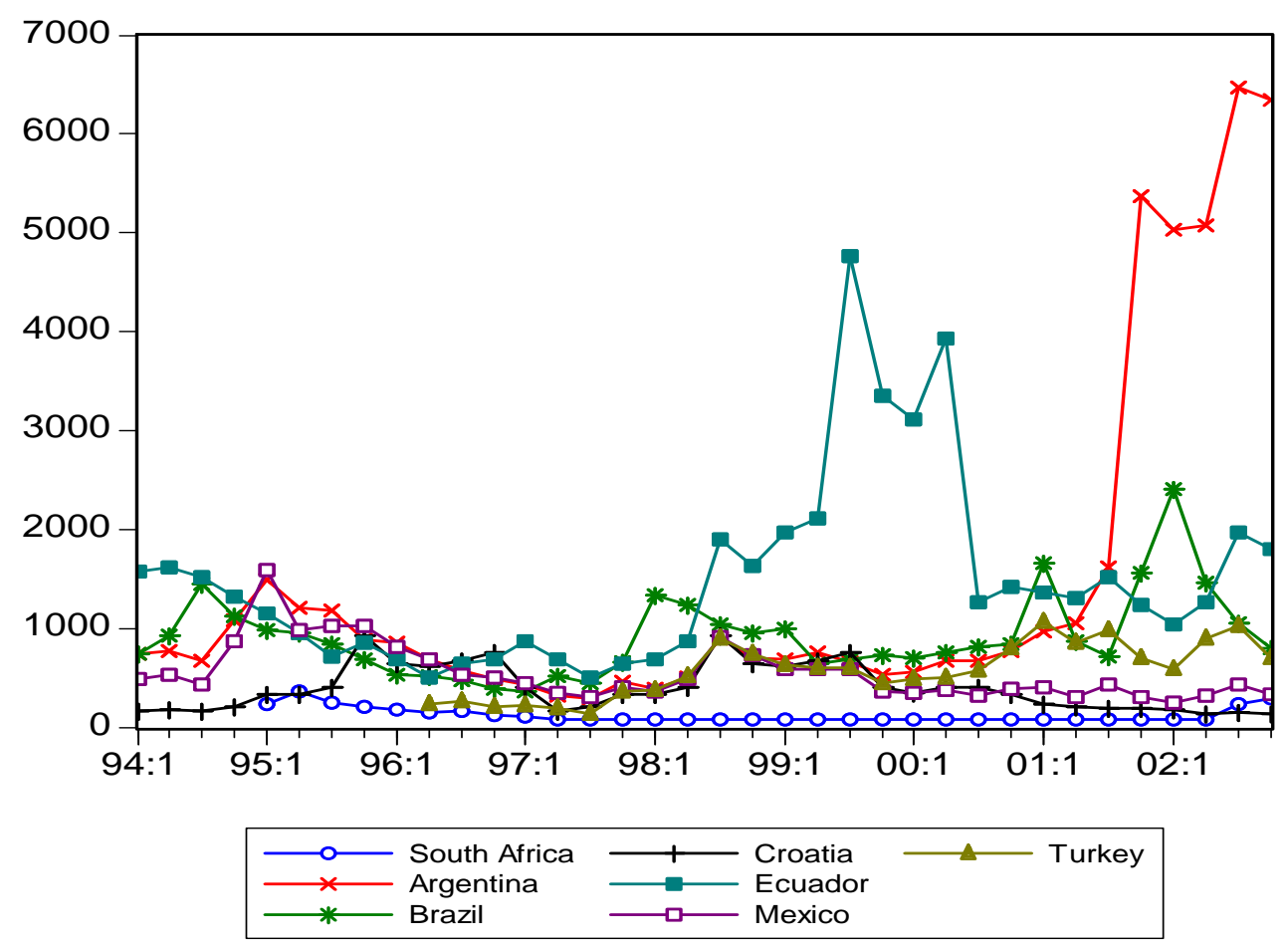




\section{REFERENCES}

Andritzky, J.R., G.J. Bannister, and N.T. Tamirisa, 2007, "The Impact of Macroeconomic Announcements on Emerging Market Bonds," Emerging Market Review, 8, 20-37.

Arora, V., and M. Cerisola, 2001, "How Does U.S. Monetary Policy Influence Sovereign Spreads in Emerging Markets?,” IMF Staff Papers, 48, 474-498.

Beck, N., and J.N. Katz, 1996, "Nuisance vs. Substance: Specifying and Estimating TimeSeries-Cross-Section Models,” Political Analysis, 6, 1-36.

Cady, J., 2005, "Does SDDS Subscription Reduce Borrowing Costs for Emerging Market Economies?,” IMF Staff Papers, 52, 503-517.

Christofides, C., C.B. Mulder, and A. Tiffin, 2003, “The Link between Adherence to International Standards of Good Practice, Foreign Exchange Spreads, and Ratings,” IMF Working Paper, No. 03/74.

Edwards, S., 1984, "LDC Foreign Borrowing and Default Risk: An Empirical Investigation,” American Economic Review, 74, 726-734.

Eichengreen, B., and A. Mody, 2000, What Explains the Changing Spreads on Emerging Market Debt?, in Edwards S. (Eds.), The Economics of International Capital Flows, University of Chicago Press.

Ferrucci, G., 2003, "Empirical Determinants of Emerging Market Economies' Sovereign Bond Spreads,” Bank of England Working Paper, No. 205.

Gelos, R.G., and S-J. Wei, 2002, “Transparency and International Investor Behavior,” NBER Working Paper No. 9260.

Glennerster, R., and Y. Shin, 2003, "Is Transparency Good for You, and Can the IMF Help?,” IMF Working Paper, No. 03/132.

Hicks, A., 1994, Introduction to Pooling, in T. Janoski and A. Hicks (edited by), The Comparative Political Economy of the Welfare State, Cambridge University Press.

Institute of International Finance, Inc. (2002), IIF Action Plan Proposals and Dialogue with the Private Sector, Appendix D: Does Subscription to the IMF's Special Data Dissemination Standard Lower a Country's Credit Spread?, The Global Association of Financial Institutions (Washington).

International Monetary Fund (2004), Global Financial Stability Report, World Economic and Financial Surveys (Washington).

Jüttner, D.J., D. Chung, and W. Leung, 2006, "Emerging Market Bond Returns - an Investor Perspective,” Journal of Multinational Financial Management, 16, 105-121.

Kamin, S.B., and K.V. Kleist, 1999, "The Evolution and Determinants of Emerging Market Credit Spreads in the 1990s,” Bank for International Settlements Working Paper, No. 68.

Min, H-G., D-H. Lee, C. Nam, M-C. Park, and S-H. Nam, 2003, "Determinants of EmergingMarket Bond Spreads: Cross-country Evidence,” Global Finance Journal, 14, 271-286. 


\section{APPENDIX}

Key Standards endorsed by the IMF and World Bank

\begin{tabular}{|c|c|c|}
\hline Subject areas & Key standards & Issuing institutions \\
\hline \multicolumn{3}{|c|}{ Macroeconomic policy and data transparency } \\
\hline $\begin{array}{l}\text { Monetary and financial policy } \\
\text { transparency }\end{array}$ & $\begin{array}{l}\text { Code of Good Practices on } \\
\text { Transparency in Monetary and } \\
\text { Financial policies }\end{array}$ & IMF \\
\hline Fiscal policy transparency & $\begin{array}{l}\text { Code of Good Practices in Fis- } \\
\text { cal Transparency }\end{array}$ & IMF \\
\hline Data dissemination & $\begin{array}{l}\text { Special Data Dissemination } \\
\text { Standard (SDDS)/General Data } \\
\text { Dissemination System (GDDS) }\end{array}$ & IMF \\
\hline \multicolumn{3}{|c|}{ Institutional and market infrastructure } \\
\hline Insolvency & $\begin{array}{l}\text { Principles and Guidelines on } \\
\text { Effective Insolvency and Credi- } \\
\text { tor Rights System }\end{array}$ & World Bank \\
\hline Corporate Governance & $\begin{array}{l}\text { Principles of Corporate Gov- } \\
\text { ernance }\end{array}$ & OECD \\
\hline Accounting & $\begin{array}{l}\text { International Accounting Stan- } \\
\text { dards (IAS) }\end{array}$ & $\begin{array}{l}\text { International Accounting Stan- } \\
\text { dards Board (IASB) }\end{array}$ \\
\hline Auditing & $\begin{array}{l}\text { International Standards on } \mathrm{Au}- \\
\text { diting (ISA) }\end{array}$ & $\begin{array}{l}\text { International Federation of Ac- } \\
\text { countants (IFAC) }\end{array}$ \\
\hline Payment and Settlement & $\begin{array}{l}\text { Core Principles for Systemati- } \\
\text { cally Important Payment Sys- } \\
\text { tems } \\
\text { Recommendations for Securi- } \\
\text { ties Settlements Systems }\end{array}$ & $\begin{array}{l}\text { Committee on Payment and } \\
\text { Settlement Systems (CPSS) } \\
\text { CPPS and International Organi- } \\
\text { zation of Securities Commis- } \\
\text { sions (IOSCO) }\end{array}$ \\
\hline Money Laundering & $\begin{array}{l}\text { The Forty Recommendations/ } 8 \\
\text { special Recommendations } \\
\text { Against Terrorist Financing } \\
\end{array}$ & $\begin{array}{l}\text { Financial Action Task Force } \\
\text { (FATF) }\end{array}$ \\
\hline \multicolumn{3}{|c|}{ Financial Regulation and supervision } \\
\hline Banking Supervision & \begin{tabular}{|l|} 
Core Principles for Effective \\
Banking Supervision \\
\end{tabular} & $\begin{array}{l}\text { Basel Committee on Banking } \\
\text { Supervision (BCBS) }\end{array}$ \\
\hline Securities Regulation & $\begin{array}{l}\text { Objectives and Principles of } \\
\text { Securities Regulation }\end{array}$ & $\begin{array}{l}\text { International Organization of } \\
\text { Securities Commissions (IO- } \\
\text { SCO) }\end{array}$ \\
\hline Insurance Supervision & Insurance Core Principles & $\begin{array}{l}\text { International Association of } \\
\text { Insurance (IAIS) }\end{array}$ \\
\hline
\end{tabular}

Source: Financial Stability Forum. 